\title{
Marked Differences in Butterfly Assemblage Composition between Forest Types in Central Amazonia, Brazil
}

\author{
Isabela Freitas Oliveira ${ }^{1,2, *}$, Fabricio Beggiato Baccaro ${ }^{3} \oplus$, Fernanda P. Werneck ${ }^{4} \oplus$, Thamara Zacca ${ }^{5}$ and \\ Torbjørn Haugaasen ${ }^{2}$ (1) \\ 1 Programa de Pós-Graduação em Ecologia, Instituto Nacional de Pesquisas da Amazônia-INPA, \\ Av. André Araújo, 2936, Manaus 69067-375, Brazil \\ 2 Faculty of Environmental Sciences and Natural Resource Management, Norwegian University of Life \\ Sciences-NMBU, P.O. Box 5003, 1432 Ås, Norway; torbjorn.haugaasen@nmbu.no \\ 3 Departamento de Biologia, Universidade Federal do Amazonas-UFAM, Av. Gen. Rodrigo Octávio, 6200, \\ Manaus 69080-900, Brazil; fabricera@gmail.com \\ 4 Coordenação de Biodiversidade, Programa de Coleções Científicas Biológicas, Instituto Nacional de \\ Pesquisas da Amazônia-INPA, Av. André Araújo, 2936, Manaus 69067-375, Brazil; fewerneck@gmail.com \\ 5 Departamento de Entomologia, Museu Nacional-UFRJ, Rua Gen. Herculano Gomes, \\ Rio de Janeiro 20941-360, Brazil; zacca.butterfly@gmail.com \\ * Correspondence: isabela.biologia@gmail.com
}

check for updates

Citation: Oliveira, I.F.; Baccaro, F.B.; Werneck, F.P.; Zacca, T.; Haugaasen, T. Marked Differences in Butterfly Assemblage Composition between Forest Types in Central Amazonia, Brazil. Forests 2021, 12, 942. https:// doi.org/10.3390/f12070942

Academic Editor: Pasi Rautio

Received: 21 June 2021

Accepted: 15 July 2021

Published: 17 July 2021

Publisher's Note: MDPI stays neutral with regard to jurisdictional claims in published maps and institutional affiliations.

Copyright: (c) 2021 by the authors. Licensee MDPI, Basel, Switzerland. This article is an open access article distributed under the terms and conditions of the Creative Commons Attribution (CC BY) license (https:// creativecommons.org/licenses/by/ $4.0 /)$.

\begin{abstract}
Amazonia comprises a mosaic of contrasting habitats, with wide environmental heterogeneity at local and regional scales. In central Amazonia, upland forest (terra firme) is the predominant forest type and seasonally flooded forests inundated by white- and black-water rivers (várzea and igapó, respectively) represent around $20 \%$ of the forested areas. In this work, we took advantage of a natural spatial arrangement of the main vegetation types in central Amazonia to investigate butterfly assemblage structure in terra firme, várzea and igapó forests at the local scale. We sampled in the low- and high-water seasons, combining active and passive sampling with traps placed in both the understory and canopy. Terra firme supported the highest number of butterfly species, whereas várzea forest provided the highest number of butterfly captures. The high species richness in terra firme may reflect that this forest type is floristically richer than várzea and igapó. Várzea is a very productive environment and may thus support a higher number of butterfly individuals than terra firme and igapó. Most butterfly species (80.2\%) were unique to a single forest type and 17 can be considered forest type indicator species in this landscape. Floodplain forest environments are therefore an important complement to terra firme in terms of butterfly species richness and conservation in Amazonia.
\end{abstract}

Keywords: butterflies; floodplain forest; indicator species; lepidoptera; species composition

\section{Introduction}

Amazonia is widely recognized as the most biodiverse biome in the world [1-3]. This high diversity is associated with the massive size of the biome, but is also partly explained by its high habitat heterogeneity. Due to the differences in topography, soil and water properties, high forest heterogeneity may be observed at both the local and regional scales [4-6] with consequences for the associated fauna [7].

At the regional scale, the main macrohabitats are unflooded forests (hereafter, terra firme) and seasonally flooded forests inundated by white- and black-water rivers (hereafter, várzea and igapó, respectively). Terra firme forests lie above the maximum flood levels of lakes and rivers and account for more than $82 \%$ of Amazonia [8]. In contrast, flooded forests are situated on floodplains and cover approximately $17 \%$ of the basin [9]. The biota in these forests must endure floods for up to 6 months per year [10]. However, várzea and igapó forests differ significantly due to the type of water that inundate them [11,12]. White-water rivers flooding várzea forests carry large amounts of nutrient-rich sediments from the Andes and pre-Andean regions $[13,14]$. These floodplains are therefore exceptionally productive 
due to the deposition of these sediments with the annual floods [14]. The black-water rivers inundating igapó forests are, on the other hand, relatively nutrient poor and more acidic [11,14].

These environmental differences lead to pronounced changes in forest structure and in floral and faunal composition between the different forest types. Previous studies have, for example, shown that assemblages of trees [11,12,15], ants [16], primates [17], bats [18,19], birds [20], and terrestrial vertebrates [21] differ significantly between these forest types. Typically, terra firme contains the highest number of species, followed by várzea and igapó. However, the Amazonian floodplain forests are probably some of the most species-rich flooded forests in the world [11,22].

At local scales, habitat heterogeneity may also be high. The topographic gradient of the floodplains influences the height and duration of the flood pulse [12,23], which has been shown to be an important predictor of tree alpha diversity and tree species distributions for both várzea $[13,22,24,25]$ and igapó $[26,27]$. Many ecological processes, such as flowering and fruiting cycles, are similarly closely tied to the seasonal floods [28,29]. Small topographic differences may also induce habitat heterogeneity in terra firme forests that, in turn, may affect several terrestrial taxa [30-33].

Model organisms are good alternatives to standardize and/or delimit ecological patterns among heterogeneous environments and their associated biotas [34,35]. Butterflies are often recognized as good model organisms due to a relatively robust taxonomic resolution, their great abundance and diversity, and intimate host plant specificity in the larval stage $[36,37]$. This renders them a relevant indicator group of environmental change [38,39], such as changes in microclimate and host plant availability [35,40,41]. Most butterfly species therefore have a clear environmental preference. For example, some species are found largely in open areas, others in forest environments. In forests, some are more adapted to the forest understory, others to the canopy [42-44]. Although butterflies are charismatic animals and well-known animals $[35,38]$, there is a conspicuous lack of inventories and ecological studies of these organisms in the Brazilian Amazon [45,46].

In this study, we present the first comparison of butterfly assemblage composition in adjacent terra firme, várzea, and igapó forests. More specifically, we investigated whether species richness and abundance differed, and how assemblage composition varied among the forest types. We expected to find that each forest type has a characteristic assemblage composition, reflecting their environmental uniqueness. Species richness was expected to be highest in terra firme due to the greater forest heterogeneity and lack of seasonal floods, whereas abundance was expected to be highest in várzea and lowest in igapó due to their contrasting productivity. Results are interpreted considering the differences experienced by seasonal flooding, soil fertility, and forest structure. Finally, we list potential indicator species of each forest type in this Amazonian landscape.

\section{Materials and Methods}

\subsection{Study Area}

This study was conducted at Uauaçu Lake $\left(4^{\circ} 14^{\prime} \mathrm{S}, 62^{\circ} 17^{\prime} \mathrm{W}\right)$, located in the lower Purus region near the confluence between the Purus and Solimões Rivers, central Amazonia, Brazil (Figure 1). Most of the sampling area is part of the Piagaçu-Purus Sustainable Development Reserve and data collection was carried out from October to November 2018 (low-water season) and from May to June 2019 (high-water season). The forests in this area remain largely undisturbed and include a unique landscape mosaic containing terra firme, várzea, and igapó. Despite being located close to two major white-water rivers, Uauaçu Lake itself is a large crescent-shaped, black-water lake fed by water draining from the surrounding terra firme forest [15]. Igapó forests are located on the floodplains along the lake margins, whereas an extensive várzea forest occurs on the floodplain squeezed between the Purus and Solimões Rivers (Figure 1). 


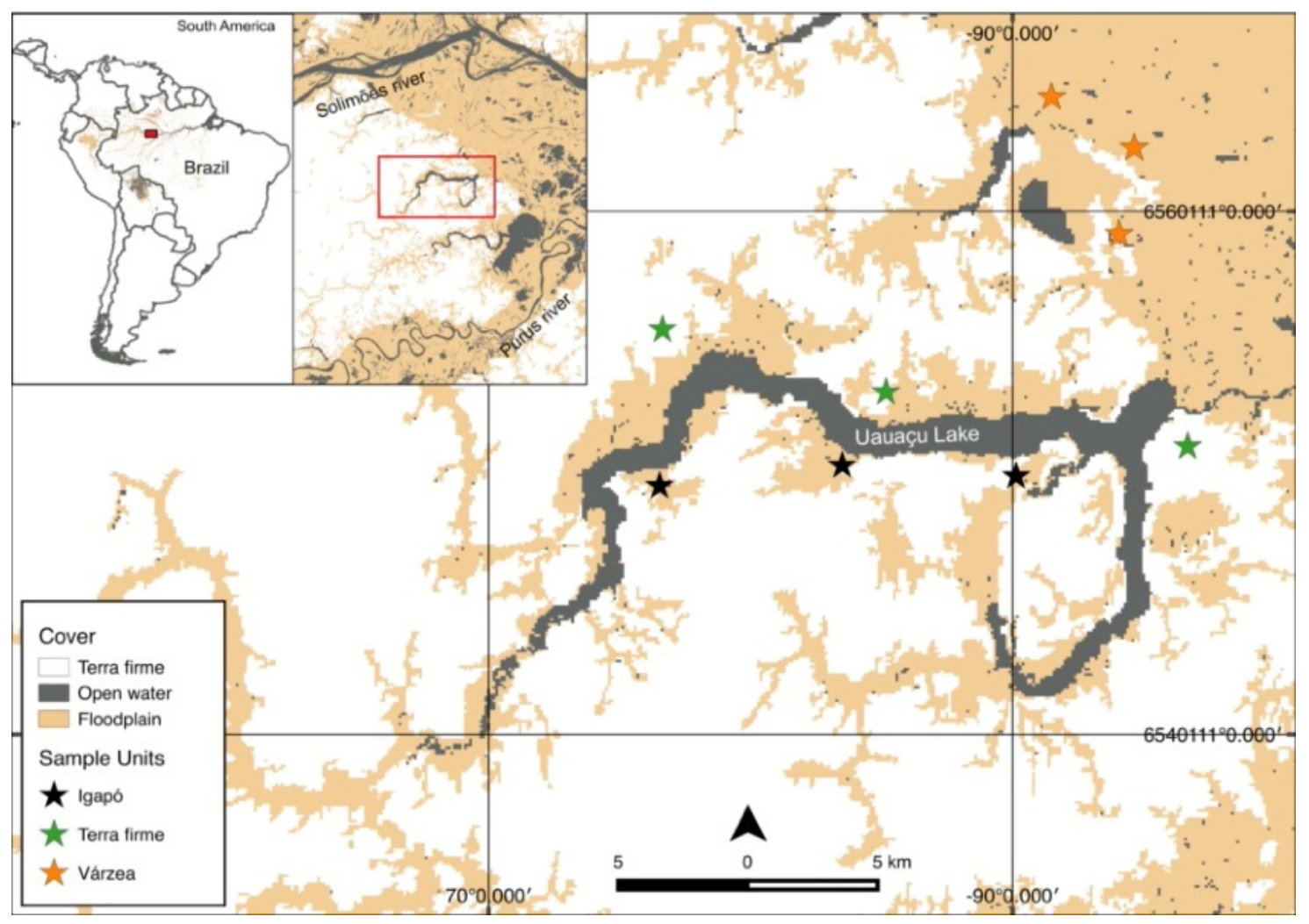

Figure 1. Location of the study and sampling points in the Uauaçu Lake region, state of Amazonas, Brazil. Black stars = igapó, green stars = terra firme, and orange stars = várzea .

\subsection{Sampling Design}

Butterfly sampling was performed along three $2 \mathrm{~km}$ transects in each forest type (Figure 1). We sampled the same transects in both the low-water and high-water season using cylindrical Van Someren-Rydon type traps [47] and an entomological net. Traps were installed and checked using a canoe in flooded forests during the high-water season. Twenty traps (ten in the canopy and ten in the understory) containing bait composed of fermenting bananas and brown sugar were placed $200 \mathrm{~m}$ apart along each transect. Canopy trap heights varied according to the local forest stature. Each trap was kept open for four days and checked every $48 \mathrm{~h}$, totaling 1440 trap days. This sampling effort is sufficient to detect approximately $70 \%$ of the fruit-feeding butterfly species in the region [48] In order to sample individuals from other families and feeding guilds, we also used standardized active searches with an entomological net. During active searches (performed simultaneously with checking traps), the collector covered the transects at $1 \mathrm{~km} / \mathrm{h}$ and collected all butterflies sighted up to $2.5 \mathrm{~m}$ on each side of the transect $[49,50]$. In flooded forests during the high-water season, active searches were performed from a canoe. The active searches were performed at different times of the day (e.g., early morning, late morning, early afternoon, and late afternoon) to sample species with different activity patterns and were rotated among forest types.

Butterflies were identified to species and subspecies level using online guides (e.g., www.butterfliesofamerica.com, www.neotropicalbutterflies.com) and the taxonomic literature [51-55]. We used taxonomic references to confirm the current taxonomy of cryptic butterflies [56-63] and all butterfly identifications were verified by an expert taxonomist. All collected butterflies were deposited in the Entomological Collection of the National Institute of Amazonian Research (INPA) and some individuals of the most abundant species were also deposited in the Zoological Collection of the Federal University of Amazonas (UFAM) and at the National Museum (UFRJ). 


\subsection{Statistical Analysis}

All butterflies sampled by active searches and in traps (both strata) were pooled by transect. The sample unit for all analyses is therefore transect in each season. We used rarefaction curves to compare and estimate species richness among forest types with different numbers of individuals collected [64]. The interpolated and extrapolated values are based on Hill numbers $(\mathrm{qD}=0)$ generated in the iNEXT package [65].

To check whether butterfly species composition differed within and between forest types, we performed a permutational multivariate analysis of variance (PERMANOVA) based on the Bray-Curtis dissimilarity measure. Forest type (terra firme, várzea, and igapó) was the dependent variable, and $p$-values were calculated based on 999 permutations. To visualize the assemblage composition in each forest type, we plotted a non-metric multidimensional scaling (NMDS) ordination using the Bray-Curtis dissimilarity index, using metaMDS function in the vegan package [66].

We performed an IndVal analysis [67] using the multipatt function in the indicspecies package to identify indicator species of each forest type. In this case, IndVal components " $\mathrm{A}$ " and " $\mathrm{B}$ " reflect how specific a species is to a particular forest type and how frequently it is found in sample units belonging to this forest type, respectively [68]. All analyses were performed using the R Studio program [69].

\section{Results}

\subsection{The Uauaçu Lake Butterfly Community}

We sampled a total of 726 individuals from 192 species representing six butterfly families: Nymphalidae (102 species, 526 individuals), Riodinidae (50 species, 141 individuals), Hesperiidae (18 species, 26 individuals), Lycaenidae (12 species, 17 individuals), Pieridae (5 species, 10 individuals), and Papilionidae (5 species, 6 individuals, Table S1). The most abundant subfamily was Satyrinae (384 individuals, 51 species), followed by Riodininae (119 individuals, 42 species), and Biblidinae (60 individuals, 15 species). The most abundant subfamily in each forest type was Satyrinae with 154, 191, and 39 individuals in terra firme, várzea, and igapó, respectively. The most abundant species in each forest type was Pierella lena brasiliensis (C. Felder \& R. Felder, 1862) (terra firme), Taygetis mermeria (Cramer, 1776) (várzea), and Chloreuptychia chlorimene (Hübner, 1819) (igapó).

\subsection{Butterfly Richness and Abundance}

Terra firme supported the highest number of species $(n=101)$, followed by várzea $(n=74)$ and igapó $(n=65)$. Várzea had the highest butterfly abundance $(n=297)$, followed by terra firme $(n=287)$ and igapó $(n=142)$. Rarefaction curves did not reach an asymptote for any of the forest types (Figure 2), suggesting that more species would likely be added to the species inventory with increased sampling effort. However, the interpolated and extrapolated curves show that terra firme has a steeper increase in expected number of species and igapó would have more species than várzea if the sampling effort was increased (Figure 2).

Few species were found in more than one environment (Figure 3). Várzea and terra firme shared the same number of species $(n=12)$ with igapó. Species exclusive to terra firme comprised $39.1 \%(n=75)$ of the sampled species richness, whereas $25 \%(n=48)$ and $16.1 \%(n=31)$ of species were exclusive to várzea and igapó, respectively (Figure 3$)$. In addition, most species were rare. Overall, 124 species were singletons $(n=95)$ or doubletons $(n=29)$ accounting for $64.6 \%$ of the total species richness, but only $21 \%$ of the sampled individuals $(n=153)$. The five most abundant species in terra firme, várzea, and igapó accounted for $31 \%(n=88), 41 \%(n=123)$, and $30 \%(n=43)$ of all individuals captured in each forest type, respectively. 


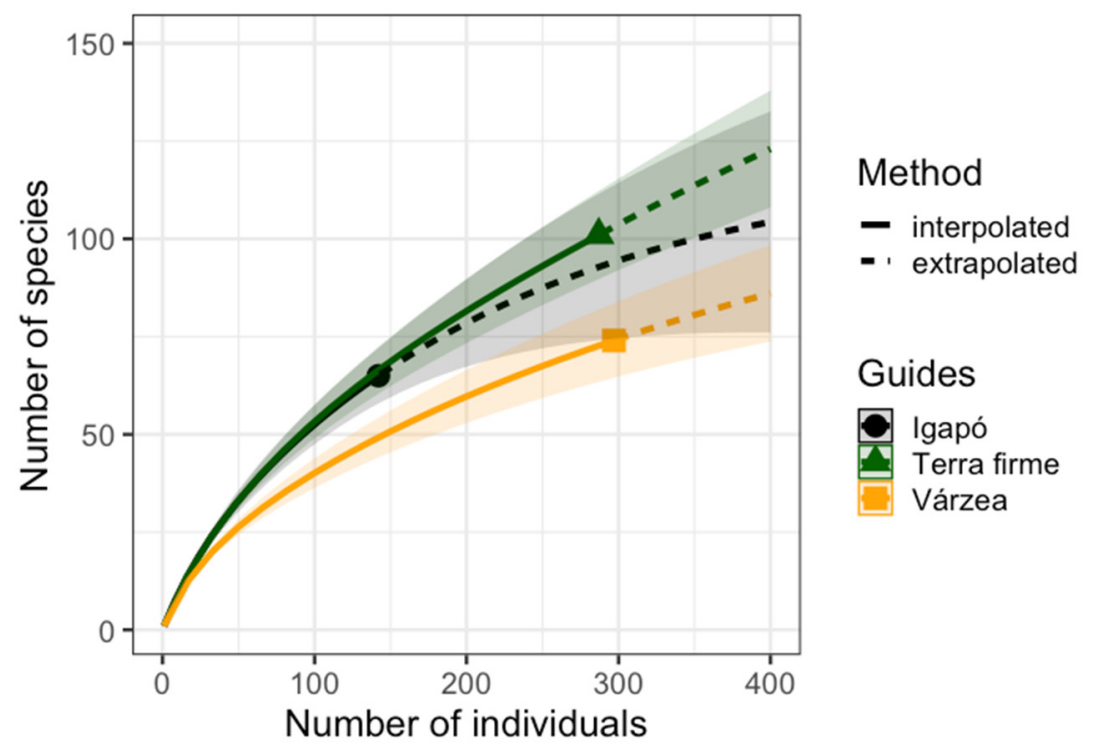

Figure 2. Species accumulation curves (interpolated and extrapolated) for the butterfly assemblages in three forest types in the lower Purus region, central Amazonia, Brazil. The solid lines show the cumulative number of species as a function of the number of individuals sampled in terra firme (green triangle and lines), várzea (yellow square and lines), and igapó (black circle and lines). Dashed lines indicate the extrapolated species number with a standardized number of individuals $(n=400)$ in each forest type and the shaded areas represent $95 \%$ confidence intervals.

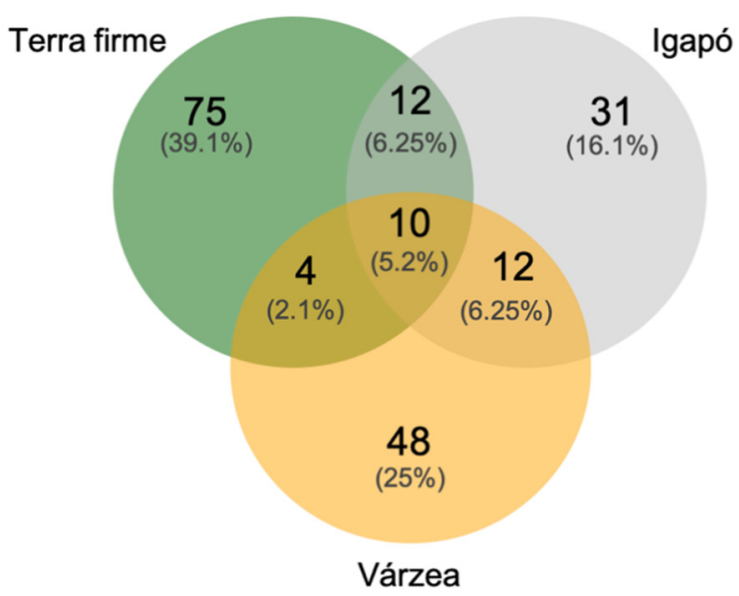

Figure 3. Venn diagram of the number and percentage of species exclusive to or shared between each forest type at Uauaçu Lake, central Amazonia, Brazil.

\subsection{Butterfly Assemblage Composition}

Butterfly assemblage composition differed between terra firme, várzea, and igapó (PERMANOVA, $\mathrm{F}_{2,17}=4.47, p=0.001$ ). This can be clearly observed in the NMDS diagram, which shows that samples distinctly cluster by forest type (Figure 4).

The indicator species analysis identified 17 species that can be considered forest type indicators (Table 1). Terra firme had nine indicator species, várzea had five, and igapó had three. 


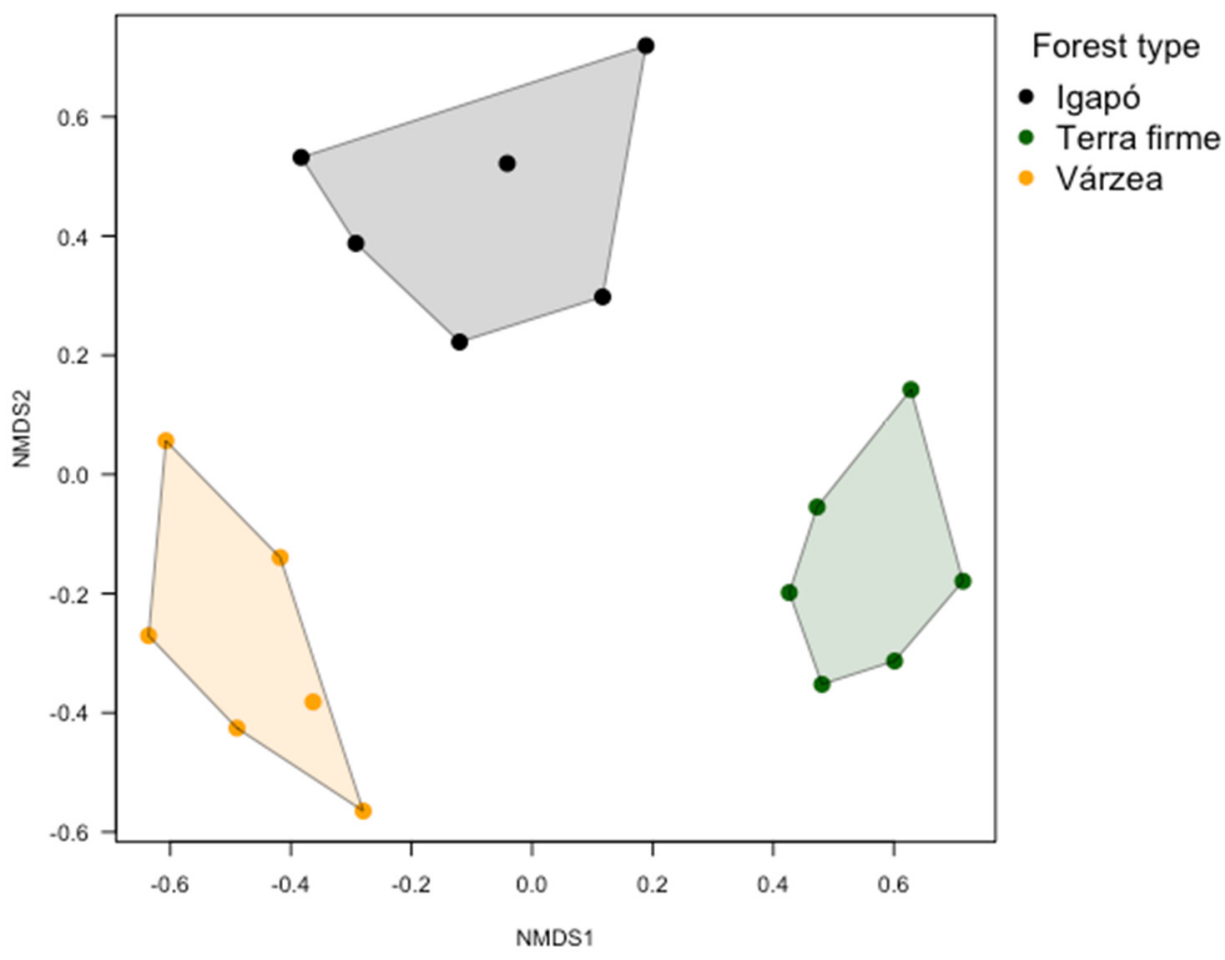

Figure 4. NMDS ordination of the butterfly assemblages in terra firme, várzea, and igapó at Uauaçu Lake, central Amazonia, Brazil. Green circles are terra firme, orange circles are várzea, and grey circles are igapó sample units.

Table 1. Butterfly indicator species for the three forest types at Uauaçu Lake, central Amazonia, Brazil. Records = species abundance and number of sample units in which the species was sampled (in parenthesis). Stat = the percentage of the IndVal combination of " $\mathrm{A}$ " (specificity) and " $\mathrm{B}$ " (fidelity). $p=$ probability of the indicator value.

\begin{tabular}{|c|c|c|c|c|}
\hline Indicator Species & Forest Type & Records & Stat & $p$ \\
\hline Nubila nortia (Hewitson, 1862) & Terra firme & $20(6)$ & $100 \%$ & 0.001 \\
\hline Bia actorion (Linnaeus, 1763) & Terra firme & $19(5)$ & $91.3 \%$ & 0.004 \\
\hline Pierella lena brasiliensis (C. Felder \& R. Felder, 1862) & Terra firme & $21(5)$ & $91.3 \%$ & 0.005 \\
\hline Cithaerias aurora (C. Felder \& R. Felder, 1862) & Terra firme & $9(4)$ & $81.6 \%$ & 0.009 \\
\hline Nymphidium baeotia (Hewitson, 1853) & Terra firme & $7(7)$ & $83.3 \%$ & 0.010 \\
\hline Haetera piera (Linnaeus, 1758) & Terra firme & $5(4)$ & $81.6 \%$ & 0.014 \\
\hline Pierella chalybaea (Godman, 1905) & Terra firme & $18(4)$ & $81.6 \%$ & 0.018 \\
\hline Scriptor sphenophorus (Lamas \& Nakahara, 2020) & Terra firme & $6(4)$ & $81.6 \%$ & 0.018 \\
\hline Taygetis laches (Fabricius, 1793) & Terra firme & $4(4)$ & $81.6 \%$ & 0.019 \\
\hline Pseudodebis marpessa (Hewitson, 1862) & Várzea & $22(6)$ & $100 \%$ & 0.001 \\
\hline Taygetis mermeria (Cramer, 1776) & Várzea & $42(5)$ & $91.3 \%$ & 0.004 \\
\hline Magneuptychia ocnus (A. Butler, 1867) & Várzea & $15(4)$ & $81.6 \%$ & 0.018 \\
\hline Taygetis rufomarginata (Staudinger, 1888) & Várzea & $9(4)$ & $81.6 \%$ & 0.016 \\
\hline Pseudodebis valentina (Cramer, 1779) & Várzea & $22(7)$ & $80.2 \%$ & 0.020 \\
\hline Archaeoprepona demophon demophon (Linnaeus, 1758) & Igapó & $6(5)$ & $91.3 \%$ & 0.002 \\
\hline Heliconius antiochus (Linnaeus, 1767) & Igapó & $12(6)$ & $83.3 \%$ & 0.014 \\
\hline Hermeuptychia undulata $^{1}$ (A. Butler, 1867) & Igapó & $6(4)$ & $81.6 \%$ & 0.014 \\
\hline
\end{tabular}

${ }^{1}$ Recently removed from Paryphthimoides [61] and placed in Hermeuptychia (Zacca et al., unpubl. data).

\section{Discussion}

This is the first study to investigate how the butterfly community is structured in adjacent, yet very distinct, terra firme, várzea, and igapó forests in central Amazonia, highlighting the relevance of environmental heterogeneity even at the local scale. As hypothesized, our results revealed a marked difference in butterfly assemblages between forest types, 
underlining a high association between butterfly species and a specific forest type present in the region.

\subsection{Species Richness and Abundance}

Terra firme supported the highest number of butterfly species, whereas várzea forest provided the highest number of butterfly captures. This is a common pattern seen for several different faunal taxa in the region, such as primates, birds, bats, and ants [16-18,70]. The slightly higher number of species sampled in terra firme may reflect that this forest type is floristically richer than várzea and igapó $[11,13]$. Previous studies showed that herbivore species richness is tightly linked to floristic diversity [71].

Due to the seasonal inundation, várzea and igapó contain fewer tree species [11,13] and may thus contain fewer potential food and larval host plants. In addition, the seasonal inundation effectively limits the use of understory habitats for up to 6 months annually, potentially leading to an impoverished understory butterfly fauna in seasonally flooded forests. Yet, the species accumulation curves did not reach an asymptote and it is likely that further butterfly species will be detected with increased sampling. Although the total number of species registered was the lowest in igapó, the species accumulation curves suggest that igapó may contain more species than várzea. A potential explanation for this finding is that igapó forests in the region are small in extent and located along the Uauaçu Lake margin and large streams entering the lake, and therefore intersect terra firme forest. In contrast, the large tract of várzea forest extends for many kilometers and most areas are thus far from terra firme. Species largely residing in terra firme forest may therefore opportunistically use igapó for resources or for simply traversing the area. A similar pattern has been observed in primates in the same study area [17,72].

Várzea forest provided the highest number of butterfly captures, despite supporting fewer species than terra firme. This high abundance is a common phenomenon found in several other taxa $[17,19]$ and is largely linked to the annual deposition of nutrient-rich silt in várzea forest that make these systems exceptionally productive [10]. As the floodwaters recede, large amounts of decomposing fruits are deposited on the forest floor [72,73], potentially providing plentiful resources for adult butterflies.

\subsection{Butterfly Assemblage Composition}

Butterfly assemblages in each forest type were markedly different. This result is consistent with previous work on other taxa in the region, such as birds [74], bats [19], and large mammals [17]. The difference between terra firme and the two floodplain forests was largely driven by the higher number of understory species, which prefer to fly close to the ground, occurring in this forest type. This is reflected by the indicator species analysis where understory species, such as low-flying Haeterini, were important indicators of terra firme. Terra firme also had more species from other butterfly tribes, such as Nymphidiini, Satyrini, Epicaliini, and Brassolini, possibly due to the higher floristic diversity in this forest type.

Várzea also supported unique assemblage but had more species in common with igapó than with terra firme, perhaps reflecting the higher floristic similarity between these two forest types compared to terra firme [15]. Interestingly, all indicator species captured in várzea belong to the Satyrini tribe. These are understory butterflies readily collected via baited traps and sweep-nets, and their host plants are mainly from the Poaceae family that are abundant in flooded environments after the water recedes [75,76].

In igapó, the most representative butterfly tribe was Preponini, and Archaeoprepona demophon demophon (Linnaeus, 1758) was an important indicator species. Despite being host-plant generalists, some of its host plants are representatives of the Fabaceae and Leguminosae families (for Prepona spp.), common in igapó [15,77], and the immature Archaeoprepona spp. are polyphagous and feed on more than one plant family $[41,78]$. Preponini have agile flight, and individuals usually stay above the canopy and visit the ground only to feed on fermented fruits and/or animal feces [79]. Igapó, which has a more open canopy and understory compared to other environments [15], seems to be an ideal 
environment for this group, providing more light to acquire energy and fewer obstacles in the forest for flight $[18,80,81]$. Other important species that were considered an indicator of igapó were Heliconius antiochus (Linnaeus, 1767) and Hermeuptychia undulata (A. Butler, 1867). The former lives in riparian forests in Amazonia and roosts over water [82]. The latter feeds Panicum sp. (Poaceae) and Schlera sp. (Cyperaceae) species, frequently found in igapó during the low-water season [12,78].

The most abundant species of each forest type and the indicator species in our study are commonly found in other regions of Amazonia. However, in this landscape context, they clearly show high forest type specificity. Despite the butterfly fauna in the Brazilian Amazonia having been studied for almost two centuries [83-85], there is a relatively small number of community ecology studies in central Amazonia that use butterflies as model organisms [44,80,86-89]. Most of these studies only sampled fruit-feeding butterflies with baited traps, which favors some Nymphalidae species. The similarity of Nymphalidae species between our study and other studies in Amazonia [87,88,90-93] is only 35\%-60\%. This is likely due to our rapid inventories in each season and limited sample sizes, as most other studies were long-term inventories [80,94] that allow a more complete sample of the butterfly fauna. However, few other studies encompassed other butterfly families [47] and our study therefore fills an important gap, presenting an updated list of all butterfly families (except Hedylidae) for this Amazonian region.

\section{Conclusions}

Our results show that each forest type contains unique species assemblages, underlining a high level of habitat specificity among butterfly species present in the region. These findings have contributed to a better understanding regarding the Amazonian butterfly fauna, its ecological specificities, and assemblage structure across different forest types in central Amazonia. Our study therefore highlights the importance of floodplain forests to the regional species pool and the importance of protecting these forests to conserve Amazonian biodiversity.

Supplementary Materials: The following are available online at https:/ / www.mdpi.com/article/10 .3390/f12070942/s1, Table S1: Butterfly species abundance in each forest type.

Author Contributions: Conceptualization and methodology, I.F.O., F.B.B. and T.H.; investigation, data curation and formal analysis, I.F.O.; writing-original draft preparation, I.F.O., F.B.B., F.P.W. and T.H.; writing-review and editing, I.F.O., F.B.B., T.Z., F.P.W. and T.H. All authors have read and agreed to the published version of the manuscript.

Funding: I.F.O. would like to thank the Coordenação de Aperfeiçoamento de Pessoal de Nível Superior-CAPES for her doctoral fellowship. The study was supported by grants from the Faculty of Environmental Sciences and Natural Resource Management (NMBU) to T.H., Fundação de Amparo à Pesquisa do Estado do Amazonas-FAPEAM (N. 016/2014 PPP) and Conselho Nacional de Desenvolvimento Científico e Tecnológico-CNPq (\#313986/2020-7) to F.B.B. T.Z. would like to thank Fundação de Amparo à Pesquisa do Estado de São Paulo-FAPESP grant (2017/02264-6). F.P.W. would like to thank CNPq for her productivity fellowship (\#311504/2020-5).

Institutional Review Board Statement: ICMBio provided the sampling license (67539-1).

Informed Consent Statement: Not applicable.

Data Availability Statement: All data that support the findings of this study are available in the Supplementary Materials of this article.

Acknowledgments: We would like to thank Evanir, Queven and Evandro de Almeida Damasceno, Kleber Almeida, Jhander Rubem and Severino Guerreiro de Brito (Assis) for providing valuable assistance during fieldwork. We would also like to thank everyone from the São João Batista community who received us and supported our research. We are indebted to Márlon Graça and Gilcélia Lourido for making traps available for the first part of the study and Roger Hutchings for providing the necessary material to pin the butterflies. Thanks to Ricardo Siewert and Fernando 
Dias for various butterfly identifications, and Luiza Martello and three anonymous reviewers for constructive comments on an earlier version of this manuscript.

Conflicts of Interest: The authors declare no conflict of interest.

\section{References}

1. Hansen, M.C.; Potapov, P.V.; Moore, R.; Hancher, M.; Turubanova, S.A.; Tyukavina, A.; Thau, D.; Stehman, S.V.; Goetz, S.J.; Loveland, T.R.; et al. High-Resolution Global Maps of 21st-Century Forest Cover Change. Science 2013, 342, 850-854. [CrossRef] [PubMed]

2. Jenkins, C.N.; Pimm, S.L.; Joppa, L.N. Global patterns of terrestrial vertebrate diversity and conservation. Proc. Natl. Acad. Sci. USA 2013, 110, E2603-E2610. [CrossRef]

3. Antonelli, A.; Zizka, A.; Carvalho, F.A.; Scharn, R.; Bacon, C.D.; Silvestro, D.; Condamine, F.L. Amazonia is the primary source of Neotropical biodiversity. Proc. Natl. Acad. Sci. USA 2018, 115, 6034-6039. [CrossRef] [PubMed]

4. Ter Steege, H.; Pitman, N.; Sabatier, D.; Castellanos, H.; Van Der Hout, P.; Daly, D.C.; Silveira, M.; Phillips, O.; Vasquez, R.; van Andel, T.; et al. A spatial model of tree alpha-diversity and tree density for the Amazon. Biodivers. Conserv. 2003, 12, $2255-2277$. [CrossRef]

5. Quesada, C.A.; Lloyd, J.; Schwarz, M.; Baker, T.R.; Phillips, O.L.; Patiño, S.; Czimczik, C.; Hodnett, M.G.; Herrera, R.; Arneth, A.; et al. Regional and large-scale patterns in Amazon forest structure and function are mediated by variations in soil physical and chemical properties. Biogeosci. Discuss. 2009, 6, 3993-4057.

6. Tuomisto, H.; Van Doninck, J.; Ruokolainen, K.; Moulatlet, G.M.; Figueiredo, F.O.G.; Sirén, A.; Cárdenas, G.; Lehtonen, S.; Zuquim, G. Discovering floristic and geoecological gradients across Amazonia. J. Biogeogr. 2019, 46, 1734-1748. [CrossRef]

7. Dambros, C.; Zuquim, G.; Moulatlet, G.M.; Costa, F.R.C.; Tuomisto, H.; Ribas, C.C.; Azevedo, R.; Baccaro, F.; Bobrowiec, P.E.D.; Dias, M.S.; et al. The role of environmental filtering, geographic distance and dispersal barriers in shaping the turnover of plant and animal species in Amazonia. Biodivers. Conserv. 2020, 29, 3609-3634. [CrossRef]

8. Melack, J.M.; Hess, L.L. Remote Sensing of the Distribution and Extent of Wetlands in the Amazon Basin. In Amazonian Floodplain Forests: Ecophysiology, Biodiversity and Sustainable Management, Ecological Studies; Springer: Dordrecht, The Netherlands, 2010; Volume 210, pp. 43-59.

9. Hess, L.L.; Melack, J.M.; Affonso, A.G.; Barbosa, C.; Gastil-Buhl, M.; Novo, E.M.L.M. Wetlands of the Lowland Amazon Basin: Extent, Vegetative Cover, and Dual-season Inundated Area as Mapped with JERS-1 Synthetic Aperture Radar. Wetlands 2015, 35, 745-756. [CrossRef]

10. Wittmann, F.; Schöngart, J.; Junk, W.J. Phytogeography, Species Diversity, Community Structure and Dynamics of Central Amazonian Floodplain Forests. In Amazonian Floodplain Forests: Ecophysiology, Biodiversity and Sustainable Management, Ecological Studies; Springer: Dordrecht, The Netherlands, 2010; Volume 210, pp. 61-102.

11. Prance, G.T. Notes on the Vegetation of Amazonia III. The Terminology of Amazonian Forest Types Subject to Inundation. Brittonia 1979, 31, 26-38. [CrossRef]

12. Junk, W.J.; Wittmann, F.; Schöngart, J.; Piedade, M.T.F. A classification of the major habitats of Amazonian black-water river floodplains and a comparison with their white-water counterparts. Wetl. Ecol. Manag. 2015, 23, 677-693. [CrossRef]

13. Junk, W.J.; Bayley, P.B.; Sparks, R.E. The Flood Pulse Concept in River-Flooding Systems. Can. Spec. Publ. Fish. Aquat. Sci. 1989, $78,110-127$.

14. Junk, W.J.; Piedade, M.T.F.; Schöngart, J.; Cohn-Haft, M.; Adeney, J.M.; Wittmann, F. A classification of major naturally-occurring amazonian lowland wetlands. Wetlands 2011, 31, 623-640. [CrossRef]

15. Haugaasen, T.; Peres, C.A. Floristic, edaphic and structural characteristics of flooded and unflooded forests in the lower Rio Purús region of central Amazonia, Brazil. Acta Amaz. 2006, 36, 25-36. [CrossRef]

16. Pringle, E.G.; Santos TF dos Gonçalves, M.S.; Hawes, J.E.; Peres, C.A.; Baccaro, F.B. Arboreal ant abundance tracks primary productivity in an Amazonian whitewater river system. Ecosphere 2019, 10, 10. [CrossRef]

17. Haugaasen, T.; Peres, C.A. Primate assemblage structure in Amazonian flooded and unflooded forests. Am. J. Primatol. 2005, 67, 243-258. [CrossRef]

18. Pereira, M.J.R.; Marques, J.T.; Santana, J.; Santos, C.D.; Valsecchi, J.; De Queiroz, H.L.; Beja, P.; Palmeirim, J. Structuring of Amazonian bat assemblages: The roles of flooding patterns and floodwater nutrient load. J. Anim. Ecol. 2009, 78, 1163-1171. [CrossRef] [PubMed]

19. Bobrowiec, P.E.D.; dos Santos Rosa, L.; Gazarini, J.; Haugaasen, T. Phyllostomid Bat Assemblage Structure in Amazonian Flooded and Unflooded Forests. Biotropica 2014, 46, 312-321. [CrossRef]

20. Laranjeiras, T.O.; Naka, L.N.; Cohn-Haft, M. Using river color to predict Amazonian floodplain forest avifaunas in the world's largest blackwater river basin. Biotropica 2019, 51, 330-341. [CrossRef]

21. Costa, H.C.M.; Peres, C.A.; Abrahams, M.I. Seasonal dynamics of terrestrial vertebrate abundance between Amazonian flooded and unflooded forests. PeerJ 2018, 6, e5058. [CrossRef]

22. Wittmann, F.; Schongart, J.; Montero, J.C.; Motzer, T.; Junk, W.J.; Piedade, M.T.F.; Queiroz, H.L.; Worbes, M. Tree species composition and diversity gradients in white-water forests across the Amazon Basin. J. Biogeogr. 2006, 33, 1334-1347. [CrossRef]

23. Wittmann, F.; Junk, W.J.; Piedade, M.T.F. The várzea forests in Amazonia: Flooding and the highly dynamic geomorphology interact with natural forest succession. For. Ecol. Manag. 2004, 196, 199-212. [CrossRef] 
24. Worbes, M.; Klinge, H.; Revilla, J.D.; Martius, C. On the dynamics, floristic subdivision and geographical distribution of várzea forests in Central Amazonia. J. Veg. Sci. 1992, 3, 553-564. [CrossRef]

25. Assis, R.L.; Wittmann, F.; Piedade, M.T.F.; Haugaasen, T. Effects of hydroperiod and substrate properties on tree alpha diversity and composition in Amazonian floodplain forests. Plant Ecol. 2015, 216, 41-54. [CrossRef]

26. Takeuchi, M. The structure of the Amazonian vegetation VI. Igapó. J. Fac. Sci. Tokyo III 1962, 8, $297-304$.

27. Keel, S.H.; Prance, G.T. Studies of the vegetation of a black-water Igapó. Acta Amaz. 1979, 9, 645-655. [CrossRef]

28. Kubitzki, K.; Ziburski, A. Seed Dispersal in Flood Plain Forests of Amazonia. Biotropica 1994, 26, 30-43. [CrossRef]

29. Haugaasen, T.; Peres, C.A. Tree phenology in adjacent Amazonian flooded and unflooded forests. Biotropica 2005, 37, 620-630. [CrossRef]

30. Vasconcelos, H.L.; Macedo, A.C.C.; Vilhena, J.M.S. Influence of topography on the distribution of ground-dwelling ants in an Amazonian forest. Stud. Neotrop. Fauna Environ. 2003, 38, 115-124. [CrossRef]

31. Rojas-Ahumada, D.P.; Landeiro, V.L.; Menin, M. Role of environmental and spatial processes in structuring anuran communities across a tropical rain forest. Austral Ecol. 2021, 37, 865-873. [CrossRef]

32. Capaverde, U.D.; do Amaral Pereira, L.G.; da Cunha Tavares, V.; Magnusson, W.E.; Baccaro, F.B.; Bobrowiec, P.E.D. Subtle changes in elevation shift bat-assemblage structure in Central Amazonia. Biotropica 2018, 50, 674-683. [CrossRef]

33. Kinap, N.M.; Nagy, M.; Paulo, R.; Bobrowiec, E.D.; Gordo, M.; Spironello, W.R. Influence of topography gradient and seasonality on primate habitat use in Central Amazonia. Mamm. Biol. 2021, 101, 251-259. [CrossRef]

34. Schulze, C.H.; Waltert, M.; Kessler, P.J.A.; Pitopang, R.; Shahabuddin, S.; Veddeler, D.; Mühlenberg, M.; Gradstein, S.R.; Leuschner, C.; Steffan-Dewenter, I.; et al. Biodiversity indicator groups of tropical land-use systems: Comparing plants, birds, and insects. Ecol. Appl. 2004, 14, 1321-1333. [CrossRef]

35. Bonebrake, T.C.; Ponisio, L.C.; Boggs, C.L.; Ehrlich, P.R. More than just indicators: A review of tropical butterfly ecology and conservation. Biol. Conserv. 2010, 143, 1831-1841. [CrossRef]

36. De Vries, P.J. Hostplant records and Natural History Notes on Costa Rican Butterflies (Papilionidae, Pieridae e Nymphalidae). J. Res. Lepid. 1986, 24, 290-333.

37. Ackery, P.R. Hostplants and classification: A review of nymphalid butterflies. Biol. J. Linn. Soc. 1988, 33, 95-203. [CrossRef]

38. Brown, K.S.; Freitas, A.V.L. Atlantic forest butterflies: Indicators for landscape conservation. Biotropica 2000, 32, 934-956. [CrossRef]

39. Freitas, A.V.L.; Francini, R.B.; Brown, K.S. Insetos como Indicadores Ambientais. In Métodos de Estudos em Biologia da Conservação e Manejo da Vida Silvestre; Cullen, L., Jr., Rudran, R., Valladares-Pádua, C., Eds.; Fundação Boticário e editora da UFPR: Curitiba, Brasil, 2003; pp. 19-41.

40. Koh, L.P.; Sodhi, N.S.; Brook, B.W. Ecological correlates of extinction proneness in tropical butterflies. Conserv. Biol. 2004, 18, 1571-1578. [CrossRef]

41. Ferrer-Paris, J.R.; Sánchez-Mercado, A.; Viloria, Á.L.; Donaldson, J. Congruence and Diversity of Butterfly-Host Plant Associations at Higher Taxonomic Levels. PLoS ONE 2013, 8, e63570. [CrossRef]

42. DeVries, P.J.; Alexander, L.G.; Chacon, I.A.; Fordyce, J.A. Similarity and difference among rainforest fruit-feeding butterfly communities in Central and South America. J. Anim. Ecol. 2012, 81, 472-482. [CrossRef]

43. Brito, M.M.; Ribeiro, D.B.; Raniero, M.; Hasui, É.; Ramos, F.N.; Arab, A. Functional composition and phenology of fruit-feeding butterflies in a fragmented landscape: Variation of seasonality between habitat specialists. J. Insect Conserv. 2014, 18, 547-560. [CrossRef]

44. Graça, M.B.; Pequeno, P.A.C.L.; Franklin, E.; Morais, J.W. Coevolution between flight morphology, vertical stratification and sexual dimorphism: What can we learn from tropical butterflies? J. Evol. Biol. 2017, 30, 1862-1871. [CrossRef]

45. Santos, E.C.; Mielke, O.H.H.; Casagrande, M.M. Butterfly inventories in Brazil: The state of the art and the priority-areas model for research aiming at conservation. Nat. Conserv. 2008, 6, 178-200.

46. Casagrande, M.M.; Mielke, O.H.H.; Carneiro, E.; Rafael, J.A.; Hutchings, R.W. Hesperioidea e Papilionoidea (Lepidoptera) coligidos em expedição aos Rios Nhamundá e Abacaxis, Amazonas, Brasil: Novos subsídios para o conhecimento da biodiversidade da Amazônia Brasileira. Rev. Bras. Entomol. 2012, 56, 23-28. [CrossRef]

47. Rydon, A. Notes on the use of butterfly traps in East Africa. J. Lepid. Soc. 1964, 18, 51-58.

48. Ribeiro, D.B.; Williams, M.R.; Specht, A.; Freitas, A.V.L. Vertical and temporal variability in the probability of detection of fruit-feeding butterflies and moths (Lepidoptera) in tropical forest. Austral Entomol. 2016, 55, 112-120. [CrossRef]

49. Pollard, E. A method for assessing changes in the abundance of butterflies. Biol. Conserv. 1977, 12, 115-134. [CrossRef]

50. Van Swaay, C.; Regan, E.; Ling, M.; Bozhinovska, E.; Fernandez, M.; Huertas, B.; Chooi-Khim, P.; Körösi, Á.; Marini-Filho, O.J.; Meerman, J.; et al. Guidelines for Standardised Global Butterfly Monitoring. Group on Earth Observations Biodiversity Observation Network, Leipzig, Germany; GEO BON Technical Series; GEO BON: Leipzig, Germany, 2015; pp. 1-32.

51. D'Abrera, B. Part I. Papilionidae and Pieridae. In Butterflies of the Neotropical Region; Hill House: Victoria, Australia, 1981; pp. 2-169.

52. D'Abrera, B. Part III. Brassolidae, Acraeidae and Nymphalidae. In Butterflies of the Neotropical Region; Hill House: Victoria, Australia, 1987; pp. 386-521.

53. D'Abrera, B. Part IV. Nymphalidae. In Butterflies of the Neotropical Region; Hill House: Victoria, Australia, 1987 ; pp. 528-678. 
54. D'Abrera, B. Part V. Nymphalidae and Satyridae. In Butterflies of the Neotropical Region; Hill House: Victoria, Australia, 1988; pp. 679-873.

55. Jiggins, C.D. The Ecology and Evolution of Heliconius Butterflies; Oxford University Press: Oxford, UK, 2017 ; pp. 1-321.

56. Constantino, L. Revisión de la tribu Haeterini Herrich-Schäffer, 1864 en Colombia. SHILAP Rev. Lepidopterol. 1995, $23,49-76$.

57. Constantino, L.M. Analisis Morfologicos, Moleculares y Biogeograficos en la Validación de Nuevas Especies y Resolución de Problemas Taxonómicos en Lepidoptera; $43^{\circ}$ Congreso Sociedad Colombiana de Entomología-SOCOLEN: Manizales, Colombia, 2016; pp. 209-228.

58. Penz, C.M.; Mohammadi, N. Diversidade de padrão das asas em Brassolini (Nymphalidae, Satyrinae). Biota Neotrop. 2013, 13, 154-180. [CrossRef]

59. Penz, C.M.; Alexander, L.G.; DeVries, P.J. Revised species definitions and nomenclature of the rose colored Cithaerias butterflies (Lepidoptera, Nymphalidae, Satyrinae). Zootaxa 2014, 3873, 541-559. [CrossRef]

60. Zacca, T.; Casagrande, M.; Huertas, B.; Barbosa, E.; Magaldi, L.; Espeland, M.; Mielke, O.; Freitas, A.; Nakahara, S.; Willmott, K. Systematics of the butterfly genus Cissia Doubleday, 1848 (Lepidoptera: Nymphalidae: Satyrinae) using an integrative approach. Arthropod Syst. Phylogeny 2018, 76, 349-376.

61. Zacca, T.; Casagrande, M.M.; Mielke, O.H.H.; Huertas, B.; Barbosa, E.P.; Freitas, A.V.L.; Lamas, G.; Espeland, M.; Brévignon, C.; Nakahara, S. Systematics of the Neotropical butterfly genus Paryphthimoides (Lepidoptera: Nymphalidae: Satyrinae), with descriptions of seven new taxa. Insect Syst. Evol. 2020, 1964, 1-55. [CrossRef]

62. Zacca, T.; Siewert, R.R.; Casagrande, M.M.; Mielke, O.H.H.; Paluch, M. Taxonomic revision of the "Pierella lamia species group" (Lepidoptera: Nymphalidae: Satyrinae) with descriptions of four new species from Brazil. Zootaxa 2016, 4078, 366-386. [CrossRef]

63. Nakahara, S.; Lamas, G.; Tyler, S.; Marín, M.A.; Huertas, B.; Willmott, K.R.; Mielke, O.H.H.; Espeland, M. A revision of the new genus Amiga Nakahara, Willmott \& Espeland, gen. N., described for Papilio arnaca fabricius, 1776 (Lepidoptera, Nymphalidae, Satyrinae). ZooKeys 2018, 2019, 85-152.

64. Colwell, R.K.; Chao, A.; Gotelli, N.J.; Lin, S.Y.; Mao, C.X.; Chazdon, R.L.; Longino, J.T. Models and estimators linking individualbased and sample-based rarefaction, extrapolation and comparison of assemblages. J. Plant Ecol. 2021, 5, 3-21. [CrossRef]

65. Hsieh, T.C.; Ma, K.H.; Chao, A. iNEXT: An R package for rarefaction and extrapolation of species diversity (Hill numbers). Methods Ecol. Evol. 2016, 7, 1451-1456. [CrossRef]

66. Oksanen, J.; Blanchet, F.G.; Friendly, M.; Kindt, R.; Legendre, P.; McGlinn, D.; Minchin, P.R.; O’Hara, R.B.; Simpson, G.L.; Solymos, P.; et al. Vegan: Community Ecology Package. R package version 2.5-6. 2019. Available online: https://CRAN.R-project.org/ package= vegan (accessed on 17 July 2021).

67. Dufrêne, M.; Legendre, P. Species assemblages and indicator species the need for flexible asymmetrical approach. Ecol. Monogr. 1997, 67, 345-366. [CrossRef]

68. Cáceres, M.; De Legendre, P.; Moretti, M. Improving indicator species analysis by combining groups of sites. Oikos 2010, 119, 1674-1684. [CrossRef]

69. R Core Team. R: A Language and Environment for Statistical Computing; R Foundation for Statistical Computing: Vienna, Austria, 2019.

70. Beja, P.; Santos, C.D.; Santana, J.; Pereira, M.J.; Marques, J.T.; Queiroz, H.L.; Palmeirim, J.M. Seasonal patterns of spatial variation in understory bird assemblages across a mosaic of flooded and unflooded Amazonian forests. Biodivers. Conserv. 2010, 19, 129-152. [CrossRef]

71. Morais, H.C.; Sujii, E.R.; Almeida-Neto, M.; De-Carvalho, P.S.; Hay, J.D.; Diniz, I.R. Host plant specialization and species turnover of caterpillars among hosts in the Brazilian cerrado. Biotropica 2011, 43, 467-472. [CrossRef]

72. Haugaasen, T.; Peres, C.A. Vertebrate responses to fruit production in Amazonian flooded and unflooded forests. Biodivers. Conserv. 2007, 16, 4165-4190. [CrossRef]

73. Hawes, J.E.; Peres, C.A. Patterns of plant phenology in Amazonian seasonally flooded and unflooded forests. Biotropica 2016, 48, 465-475. [CrossRef]

74. Haugaasen, T.; Peres, C.A. Population abundance and biomass of large-bodied birds in Amazonian flooded and unflooded forests. Bird Conserv. Int. 2008, 18, 87-101. [CrossRef]

75. Junk, W.J.; Piedade, M.T.F.; Wittmann, F.; Schöngart, J. Várzeas Amazônicas: Desafios para um Manejo Sustentável; Editora do INPA: Manaus, Brazil, 2020; pp. 1-310.

76. Kirschner, J.A.; Hoorn, C. The onset of grasses in the Amazon drainage basin, evidence from the fossil record. Front. Biogeogr. 2020, 12, e44827. [CrossRef]

77. Ferreira, L.V. Effects of the duration of flooding on species richness and floristic composition in three hectares in the Jaú National Park in floodplain forests in central Amazonia. Biodivers. Conserv. 1997, 6, 1353-1363. [CrossRef]

78. Beccaloni, G.W.; Viloria, Á.L.; Hall, S.K.; Robinson, G.S. Catalogue of the hostplants of the Neotropical butterflies/Catálogo de las plantas huésped de las mariposas neotropicales. Monogr. Terc. Milen. 2008, 8, 539.

79. Muyshondt, A. Notes on the life cycle and natural history of butterflies of El Salvador. VII. Archaeoprepona demophon centralis (Nymphalidae). J. Lepid. Soc. 1979, 30, 23-32.

80. Brown, K.J.; Hutchings, R.W. Disturbance, fragmentation, and the dynamics of diversity in Amazonian forest butterflies. In Tropical Forest Remnants: Ecology, Management, and Conservation of Fragmented Communities; Laurance, F., Bierregaard, R.O., Jr., Eds.; The University of Chicago Press: Chicago, IL, USA, 1997; pp. 91-110. 
81. Graça, M.B.; Pequeno, P.A.C.L.; Franklin, E.; Souza, J.L.P.; Morais, J.W. Taxonomic, functional, and phylogenetic perspectives on butterfly spatial assembly in northern Amazonia. Ecol. Entomol. 2017, 42, 816-826. [CrossRef]

82. Brown, K.J. The biology of Heliconius and related genera. Ann. Rev. Entomol. 1981, 26, 427-456. [CrossRef]

83. Aurivillius, P.O.C. Wissenschaftliche Ergebnisse der schwedischen entomologischen Reisen des Herrn Dr. A. Roman in Amazonas 1914-1915 und 1923-1924. 13. Rhopalocera. Entomol. Tidskrift. 1929, 50, 153-168.

84. Bates, H.W. Contributions to an insect fauna of the Amazon Valley, Lepidoptera: Heliconidae. Trans. Linn. Soc. Lond. 1862, 23, 495-566. [CrossRef]

85. Bates, H.W. The Naturalist on the River Amazons; University of California Press: Berkeley, CA, USA, $1864 ;$ p. 465.

86. Ribeiro, D.B.; Freitas, A.V.L.L. The effect of reduced-impact logging on fruit-feeding butterflies in Central Amazon, Brazil. J. Insect Conserv. 2012, 16, 733-744. [CrossRef]

87. Graça, M.B.; Morais, J.W.; Franklin, E.; Pequeno, P.A.C.L.; Souza, J.L.P.; Bueno, A.S. Combining Taxonomic and Functional Approaches to Unravel the Spatial Distribution of an Amazonian Butterfly Community. Environ. Entomol. 2016, 45, 301-309. [CrossRef] [PubMed]

88. Spaniol, R.L.; da Silva Duarte, L.; de Souza Mendonça, M.; Iserhard, C.A. Combining functional traits and phylogeny to disentangling Amazonian butterfly assemblages on anthropogenic gradients. Ecosphere 2019, 10, e02837. [CrossRef]

89. Spaniol, R.L.; de Souza Mendonça, M.; Hartz, S.M.; Iserhard, C.A.; Stevens, M. Discolouring the Amazon Rainforest: How deforestation is affecting butterfly coloration. Biodivers. Conserv. 2020, 29, 2821-2838. [CrossRef]

90. Ramos, F.A. Nymphalid butterfly communities in an amazonian forest fragment. J. Res. Lepid. 2000, 35, $29-41$.

91. DeVries, P.; Walla, T. Species diversity and community structure in neotropical fruit-feeding butterflies. Biol. J. Linn. Soc. 2001, 74, 1-15. [CrossRef]

92. Barlow, J.; Overal, W.L.; Araujo, I.S.; Gardner, T.A.; Peres, C.A. The value of primary, secondary and plantation forests for fruit-feeding butterflies in the Brazilian Amazon. J. Appl. Ecol. 2007, 44, 1001-1012. [CrossRef]

93. da Costa Araujo, E.; Martins, L.P.; Duarte, M.; Azevedo, G.G. Temporal distribution of fruit-feeding butterflies (Lepidoptera, Nymphalidae) in the eastern extreme of the Amazon region. Acta Amaz. 2020, 50, 12-23. [CrossRef]

94. Emmel, T.C.; Austin, G.T. The Tropical Rain Forest Butterfly Fauna of Rondonia, Brazil: Species Diversity and Conservation. Trop. Lepidotera 1990, 1, 1-12. 